\title{
Perancangan Sistem Informasi Absensi Dan Nilai Siswa Beserta Absensi Dan Laporan Kegiatan Guru Di Sekolah Advent Pancaran Kasih Berbasis Web
}

\author{
Boston Pahala Siahaan dan Yusran Tarihoran \\ Fakultas Teknologi Informasi, Universitas Advent Indonesia
}

\begin{abstract}
ABSTRAK
Umumnya sistem absensi dan laporan kegiatan guru di sekolah dilakukan dengan cara manual yaitu guru mengisi absensi dengan menulis di kertas data kehadiran mereka setelah itu guru juga melakukan absensi untuk siswanya dengan memanggil nama siswa satu per satu yang dilakukan oleh guru yang mengajar. Oleh karena itu, diperlukan suatu perubahan dengan proses komputerisasi untuk memperbaiki segala kekurangan dan kecurangan dalam proses absensi maupun nilai pada siswa. Sekolah Pancaran Kasih sangat ingin memiliki website sekolah yang berguna untuk memberikan informasi - informasi, absensi guru dan murid beserta nilai siswa yang lebih baik. Metode pengembangan sistem yang digunakan dalam penelitian adalah SDLC yang terdiri dari (1) Informasi, (2) perancangan, (3) penerapan, (4) pemeliharaan. Dari penelitian ini yang telah dilakukan, penulis menyimpulkan bahwa (1) Sistem ini bisa digunakan oleh guru maupun admin (2) guru dengan mudah menginput data kehadiran siswanya dan memberikan nilai kepada siswanya (3) Semua data kehadiran dan nilai siswa serta data kehadiran guru dan laporan kegiatannya akan disimpan ke sistem yang telah dibuat. Dengan dirancangnya sistem informasi absensi dan nilai siswa beserta absen dan laporan kegiatan guru maka dapat disimpulkan, sistem dapat memberikan kemudahan kepada pengguna dan administrator yang terkait dalam mengolah dan menyimpan data sehingga dapat memberikan informasi yang sesuai dengan kebutuhan pengguna.
\end{abstract}

Kata Kunci: Buku Absensi Guru, Buku Absensi Siswa, Informasi

\section{DESIGN OF ATTENDANCE SYSTEM INFORMATION AND STUDENT ATTENDANCE AND GRADE AND TEACHER'S ACTIVITIES IN ADVENTIST SCHOOL PANCARAN KASIH BASED ON WEB}

\begin{abstract}
Generally attendance system and teacher activity report in school is done by manual that is teacher fill the attendance by writing in paper of their attendance data after that teacher also doing attendance for student by calling student name one by one done by teacher teaching. Therefore, it needs a change with the computerization process to fix any deficiencies and fraud in the process of absenteeism and value on the students. Sekolah Pancaran Kasih is very eager to have a useful school website to provide information - information, teacher and student attendance along with better student scores. System development method used in this research is SDLC consisting of (1) Information, (2) design, (3) implementation, (4) maintenance. From this research which have been done, the writer conclude that (1) This system can be used by teacher and admin (2) teacher easily input student attendance data and give value to its student (3) All attendance data and student value and teacher attendance data and the activity report will be saved to the system that has been created. With the design of attendance information system and students' values along with absences and reports of teacher activities it can be concluded, the system can provide convenience to users and administrators involved in processing and storing data so as to provide information in accordance with the needs of the user.
\end{abstract}

\section{Pendahuluan}

Sekolah Advent Pancaran Kasih adalah Sekolah yang dikelola oleh jemaat GMAHK The Angel Singing. Sekolah yang berdiri sejak tahun 1964 bertanggung jawab untuk mencerdaskan anak-anak bangsa, dan memiliki kemampuan yang berdaya guna. Sekolah Advent Pancaran Kasih merupakan salah satu sekolah swasta di surabaya. Saat ini sekolah ini memiliki +-68 orang, baik Guru, Administrasi 
dan murid. Oleh sebab itu sekolah ini telah membuat sistem pendataan guru dan murid. Selain pembuatan data guru dan murid, juga menerapakan sistem absensi dan penilaian siswa. Sistem tersebut masih menggunakan pengolahan dokumen. Pengolahan data dan proses absensi guru dan murid pada sekolah masih belum memadai. Permasalahan ini menyebabkan sekolah masih tergolong lambat dalam melakukan proses pendataan dan absensi baik guru maupun murid. Di sekolah, kedisiplinan kehadiran dari siswa merupakan hal terpenting untuk kesuksesan kegiatan belajar mengajar. Absensi yang dilakukan di kelas dengan cara menuliskan di buku absen setiap hari.

Setiap akhir semester guru Bimbingan Konseling (BK) harus merekap absensi siswa guna mengisi absensi di raport siswa yang diberikan sebagai laporan kepada orang tua siswa. Orang tua siswa merupakan bagian dari kesuksesan setiap siswa.

Informasi terpenting bagi orang tua siswa yang terkait dengan kegiatan belajar disekolah seperti informasi nilai dan absensi siswa biasanya diperoleh saat pihak sekolah sudah mengumumkannya, dan informasi tersebut bisa diperoleh hanya di sekolah saja. Artinya, akan sulit bagi orang tua siswa untuk memperoleh informasi yang diinginkan pada saat kapan pun dan dimanapun. Masalah lain yang ditemukan adalah sulitnya para orang tua siswa untuk mengetahui secara detail bagaimana perilaku anaknya selama di sekolah terutama absensi anaknya.

Sekolah masih mengalamai banyak kendala dalam proses pendataaan absensi dan nilai siswa serta absen dan laporan kegiatan guru diantaranya proses pengisian tersebut masih lama, karena dilakukan dengan proses pencatatan yang terkadang dilakukan secara manual dalam kertas sehingga sering terjadi kelalaian guru dalam menyimpan data nilai siswa maupun data laporan kehadiran mereka. Oleh karena itu, diperlukan suatu perubahan untuk memperbaiki segala kekurangan dan kecurangan dalam proses absensi maupun nilai terhadap siswa

Adapun sistem penilaian yang dilakukan oleh guru di sekolah ini adalah bagaimana siswa diwajibkan untuk hadir mengikuti pelajaran sekolah, mengikuti kuis, ujian tengah semester, dan ujian akhir semester. Kemudian guru yang bersangkutan mengeluarkan nilai siswa yang telah diproses melalui ketentuan penilaian. Adapun permasalahan yang dihadapi adalah dalam memperoleh informasi nilai, siswa harus menunggu sampai akhir semester pada saat pembagian raport, begitu juga dengan dengan guru yang melakukan pengolahan data nilai siswa masih harus menghitung sendiri formula penilaian dan mengantarkan format hasil penilaian ke kantor tata usaha untuk diserahkan ke wali kelas untuk pembuatan raport, sedangkan penyampaian informasi nilai hasil ujian dengan membacakan pada saat masuk mengajar di kelas tersebut ataupun membagikan kertas hasil ujian siswa sekaligus pada saat membagi rapor. Dengan kata lain sekolah ini masih menggunakan sistem yang kurang efisien baik dalam hal jarak, waktu maupun biaya, dan dalam pengolahan data nilai siswa dimana pencatatan tidak akurat, sering terjadi duplikasi sehingga dan pembuatan rekap nilai serta laporan prestasi siswa tidak relevan dan membutuhkan waktu yang cukup lama dan informasi serta laporan kepada masyarakat maupun kepala sekolah sulit untuk di update.

\section{Landasan Teori Sistem}

Menurut Mohamad Subhan (2012:8) Suatu sistem dapat diartikan sebagai suatu kumpulan atau himpunan dari unsur, komponen, atau variabel-variabel yang terorganisasi, saling berinteraksi, saling tergantung satu sama lain dan terpadu. Sistem juga merupakan kumpulan elemen-elemen saling terkait dan bekerja sama untuk memproses masukan (input) yang ditujukan kepada sistem tersebut dan mengolah masukan tersebut sampai menghasilkan keluaran (output) yang diinginkan.

\section{Informasi}

Menurut Sutabri (2012:29) Informasi adalah data yang telah diklasifikasikan atau diinterpretasi untuk digunakan dalam proses pengamnilan keputusan. Menurut McLeod (2012:8) informasi adalah data yang diolah menjadi bentuk yang lebih berguna bagi penerimanya.

\section{Sistem Informasi}

Menurut sutarman (2012:13), Sistem Informasi adalah sistem yang dapat didefinisikan dengan mengumpulkan, memproses, menyimpan, menganalisis, menyebarkan informasi untuk tujuan tertentu.

\section{Mengajar}

Mengajar adalah bentuk usaha untuk dapat meciptakan suatu sistem lingkungan yang dapat memungkinkan untuk terjadinya proses belaajar secara optimal (Gulo:2012). 
Mengajar adalah bentuk perilaku yang kompleks. Perilaku kompleks dalam mengajar di tafsirkan sebagai penggunaaan secara integratif komponen yang ada di dalam tindakan mengajar untuk dapat menyampaikan pesan pengajaran (Roymond:2012).

\section{Nilai}

Dalam Kamus Umum Bahasa Indonesia nilai adalah harga dimana sesuatu mempunyai nilai karena dia mempunyai harga atau sesuatu itu mempunyai harga karena ia mempunyai nilai. Dan oleh karena itu nilai sesuatu yang sama belum tentu mempunyai harga yang sama pula karena penilaian seseorang terhadap sesuatu yang sama itu biasanya berlainan. Bahkan ada yang tidak memberikan nilai terhadap sesuatu itu karena ia tidak berharga baginya tetapi mungkin bagi orang lain malah mempunyai nilai yang sangat tinggi karena itu sangatlah berharga baginya.

\section{Definisi Absen}

Absensi adalah suatu pendataan kehadiran, bagian dari pelaporan aktifitas suatu institusi, atau komponen institusi itu sendiri yang berisi data-data kehadiran yang disusun dan diatur sedemikian rupa sehiingga mudah untuk dicari dan dipergunakan apabila sewaktu-waktu diperlukan oleh pihak yang bersangkutan.

\section{Analisis Sistem \\ Use Case Diagram}

Use Case Diagram merupakan pemodelan untuk menggambarkan kelakuan (behavior) sistem yang akan dibuat. Use Case Diagram mendiskripsikan sebuah interaksi antara satu atau lebih aktor dengan sistem yang akan dibuat. Yang ditunjukkan di dalam diagram Use Case ini adalah bagaimana guru dan admin bisa login atau logout sehingga akan menampilkan website Sekolah Advent Pancaran Kasih Surabaya yang akan digunakan dalam proses kegiatan sekolah. Pada tampilan atau menu dalam website tersebut terdapat home tampilan depan, absen guru, absen siswa, nilai siswa dan laporan kegiatan mengajar guru.

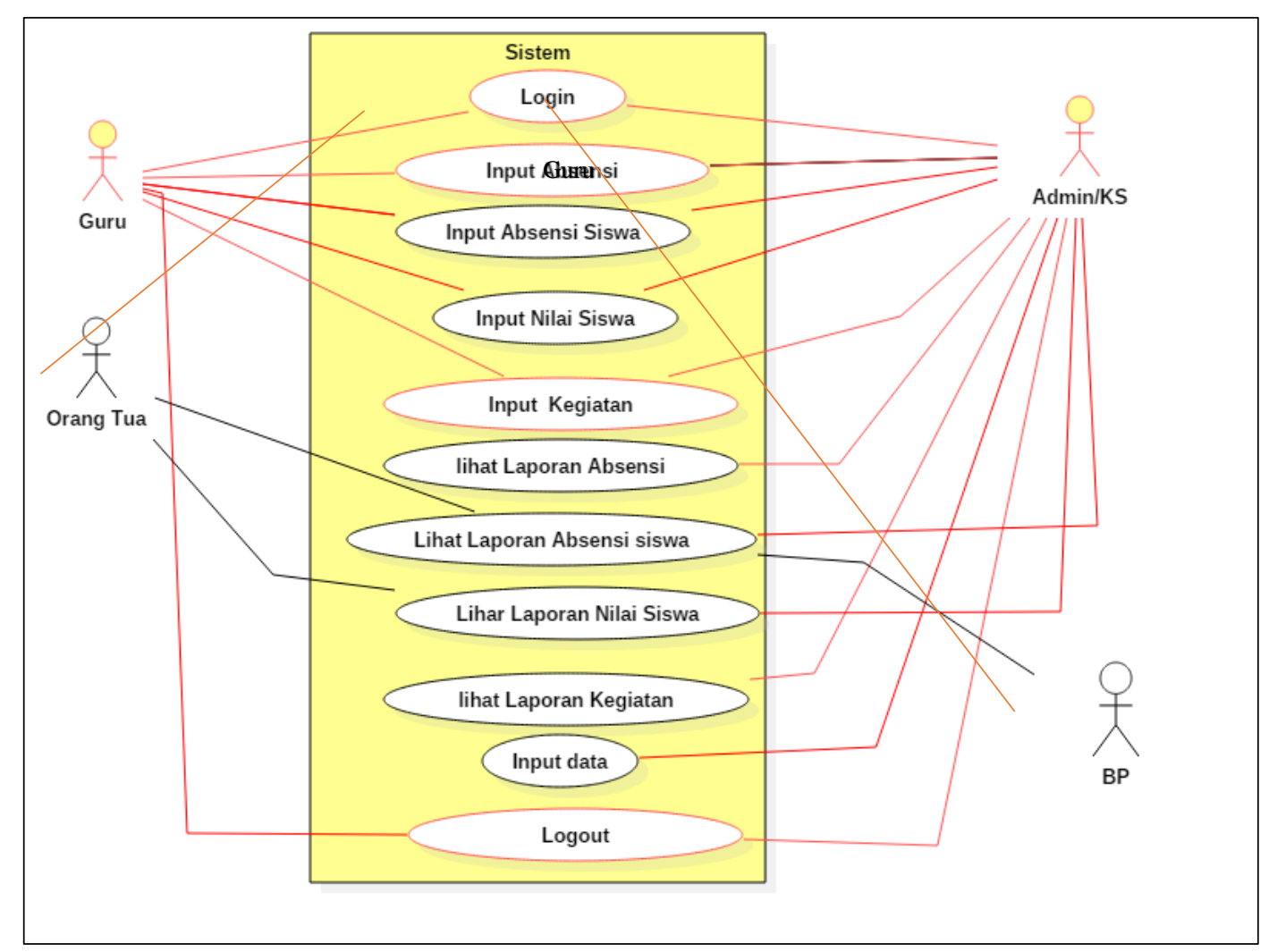

Gambar 1 Use Case Diagram

Dalam usecase diagram diatas, dapat terlihat ada 5 aktor dalam proses diatas yaitu: 
Guru, Admin, Kepala Sekolah, Guru BK dan Orang Tua

Dari gambar diatas, dapat dijelaskan fungsi-fungsinya sebagai berikut:

1. Login

Proses dimana user yang telah memiliki akun agar dapat melakukan kegiatan dalam sistem.

2. Input Absensi Guru

Proses dimana guru menginput data kehadiran.

3. Input Absensi Siswa

Proses dimana guru menginput data kehadiran siswanya.

4. Input Nilai Siswa

Proses dimana guru menginput data nilai siswanya (Quiz 1-5,UTS,UAS dan Nilai Akhir).

5. Input Laporan Kegiatan Mengajar Guru

Proses dimana guru menginput data kegiatan mengejar selama proses belajar mengajar

6. Lihat Laporan Absen Guru

Lihat lapor absen adalah proses dimana guru hanya dapat melihat laporan absen guru tersebut tetapi tidak bsia melihat laporan dari absen guru yang lain sedangkan admin bsia melihat laporan hasil absen semua guru setelah mereka melakukan pengabsenan terlebih dahulu.

7. Lihat Laporan Absen Siswa

Proses dimana wali kelas, guru Bp dan admin hanya bisa melihat hasil laporan absen siswanya yang dimana wali kelas tidak bisa melihat absen siswa dari guru yang lain sedangkan admin dan guru BP dapat melihat laporan absen siswa dari semua guru setelah mereka melakukan pengabsenan terlebih dahulu.

8. Lihat Laporan Nilai Siswa

Proses dimana orang tua dapat melihat nilai mata pelajaran anaknya sedangkan guru hanya bisa melihat hasil laporan nilai siswanya tetapi tidak bisa melihat nilai siswa dari guru yang lain sedangkan admin, kepala sekolah dan guru BP dapat melihat laporan nilai siswa dari semua guru setelah mereka melakukan penginputan nilai terlebih dahulu.

9. Lihat Laporan Kegiatan

Proses dimana guru hanya bisa melihat hasil laporan kegiatannya tetapi tidak bisa melihat laporan kegiatan dari guru yang lain dan admin dapat melihat hasil laporan kegiatan dari semua guru setelah mereka melakukan penginputan laporan kegiatan terlebih dahulu.

10. Input data

Input data adalah proses dimana admin dapat melakukan login terlebih dahulu untuk dapat memulai masuk kedalam sistem dan setelah itu dapat mengoperasikan sistem dan dapat melihat hasil keseluruhan berupa input siswa baru, mata pelajaran baru, guru baru, tahun ajaran baru, melihat laporan absen seluruh guru, meliihat absen siswa dari masing-masing guru, melihat hasil laporan nilai siswa dari masing-masing guru dan melihat hasil laporan kegiatan mengajar dari masing-masing guru.

11. Logout

Log out adalah proses dimana user yang telah memiliki akun agar dapat keluar dari kegiatan di dalam sistem.

\section{Hasil Perancangan}

Halaman absen guru digunakan untuk menginput data kehadiran guru. Input absen guru yang ditampilkan pada halaman ini adalah data waktu mulai, waktu berhenti dan total waktu. Guru mengisi data kehadiran dengan mengklik tombol mulai sehingga akan muncul waktu mulai, waktu berhenti dan total waktu. Tampilan dapat dilihat pada gambar 2 . 


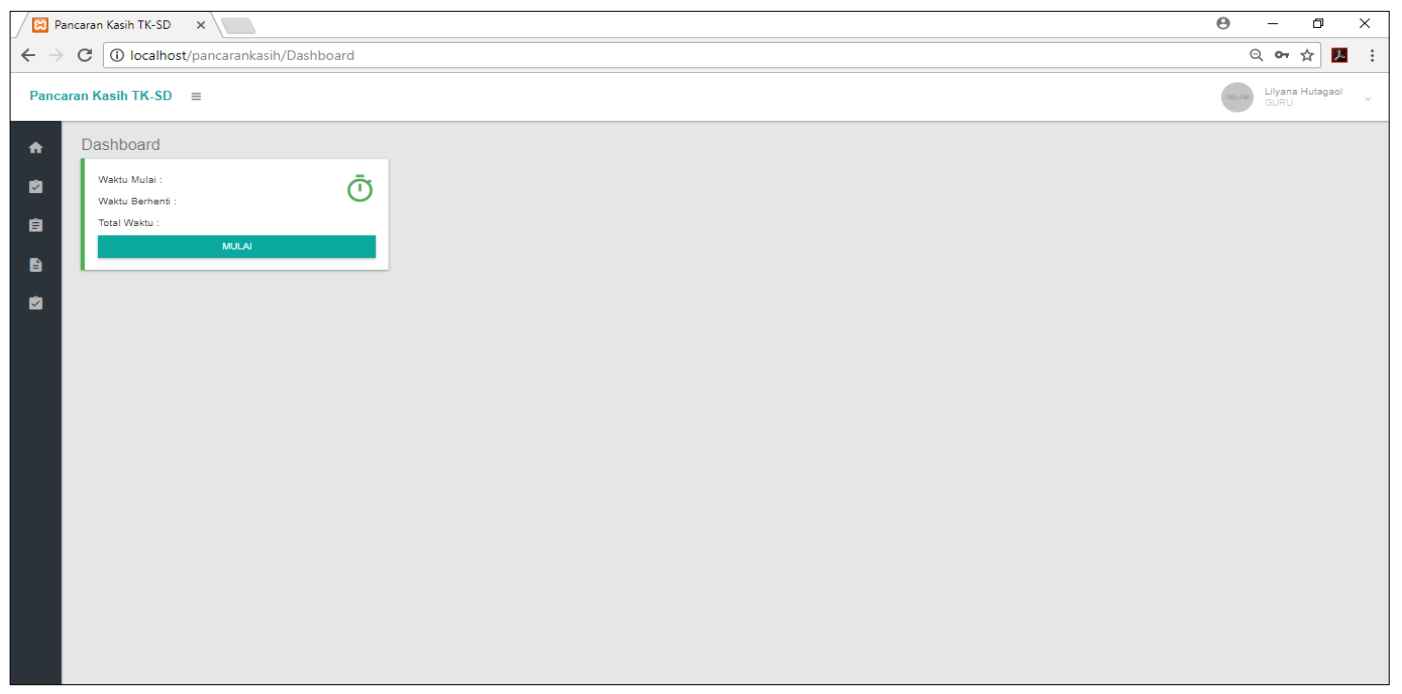

Gambar 2 Tampilan halaman absensi guru

\section{Halaman Input Absensi Siswa}

Halaman input absen siswa digunakan untuk menginput data kehadiran siswa di kelas. Data absen siswa yang ditampilkan pada halaman ini adalah data nama siswa, semester, tahun ajaran, kelas, keterangan. Guru menginput data kehadiran siswanya dengan perihal nama, kelas, tahun ajaran, keterangan. setelah itu klik tombol save. Tampilan dapat dilihat pada gambar 3.

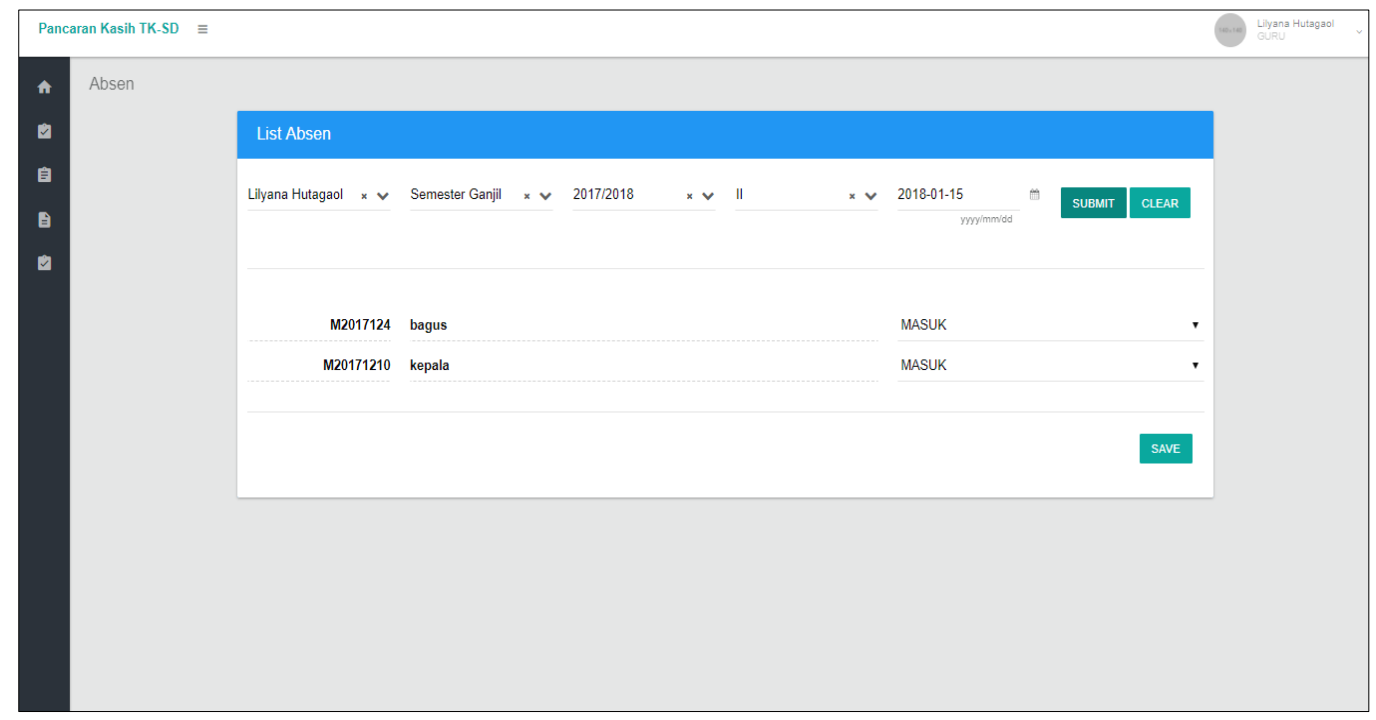

Gambar 3 Tampilan halaman absensi siswa

\section{Halaman Input Kegiatan Mengajar}

Halaman input kegiatan mengajar digunakan untuk menginput data laporan kegiatan mengajar di kelas. Data kegiatan mengajar yang ditampilkan pada tampilan adalah data tanggal, waktu, laporan kegiatan, nama guru dan kelas. Guru mengisi form kegiatan mengajar. Setelah itu klik tombol save. Tampilan dapat dilihat pada gambar 4. 


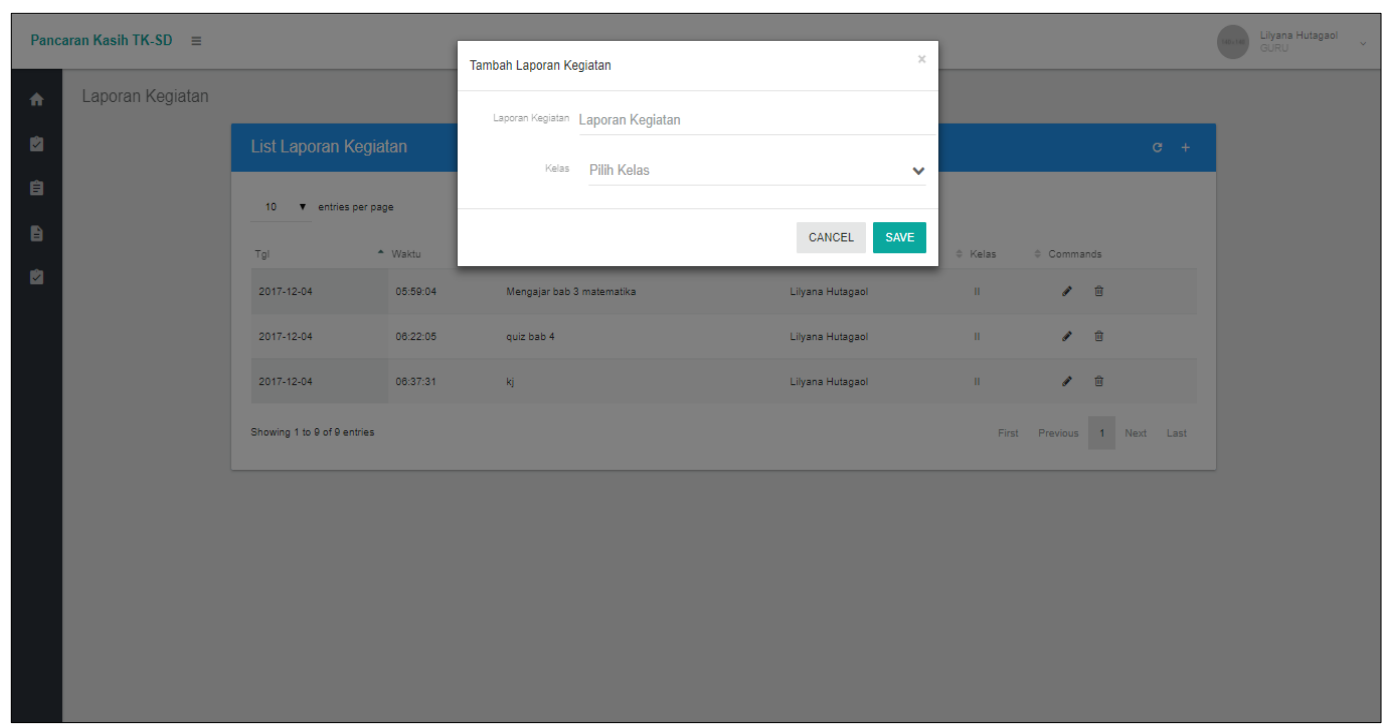

Gambar 4 Tampilan Halaman Input Kegiatan Guru

\section{Halaman Input Nilai Siswa}

Halaman input nilai siswa digunakan untuk menginput data nilai siswa di kelas. Data input nilai siswa yang ditampilkan pada halaman ini adalah data tanggal, waktu, kelas, mata pelajaran, nama siswa, Nilai kuis 1-5, Nilai UTS, Nilai UAS dan Nilai Akhir.

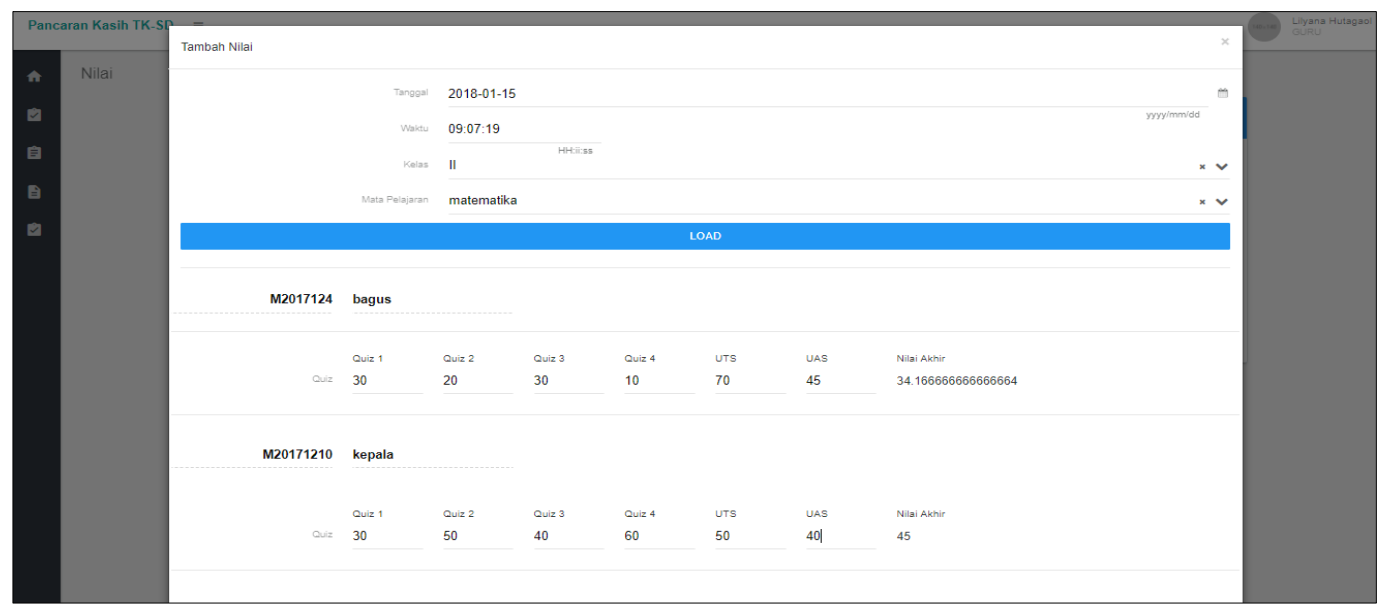

Gambar 5 Halaman Input Nilai Siswa

Guru mengisi Nilai kuis 1-4. Nilai UTS, Nilai UAS dan Nilai Akhir. sehingga untuk nilai akhir sistem otomatis akan muncul dengan nilai keseluruhan. Sehingga guru tidak perlu lagi menghitung menggunakan kalkulator untuk mengetahui nilai akhir. Maka, nilai akhir nantinya akan dimasukkan ke dalam rapot siswa. Tampilan dapat dilihat pada gambar 5 .

\section{Halaman Lihat Absen Guru}

Halaman lihat absen guru digunakan untuk menampilkan data kehadiran guru. Data llihat absen guru yang ditampilkan pada halaman ini adalah data waktu mulai, waktu berhenti dan total waktu. Setelah guru mengajar pelajaran di kelas, klik tombol berhenti. Admin dan kepala sekolah dapat melihat kehadiran seluruh guru pada saat mengajar di kelas. Dengan melihat nama guru, tanggal masuk, waktu mulai mengajar, waktu selesai mengajar dan total keseluruhan dalam mengajar. Tampilan dapat dilihat pada gambar 6. 


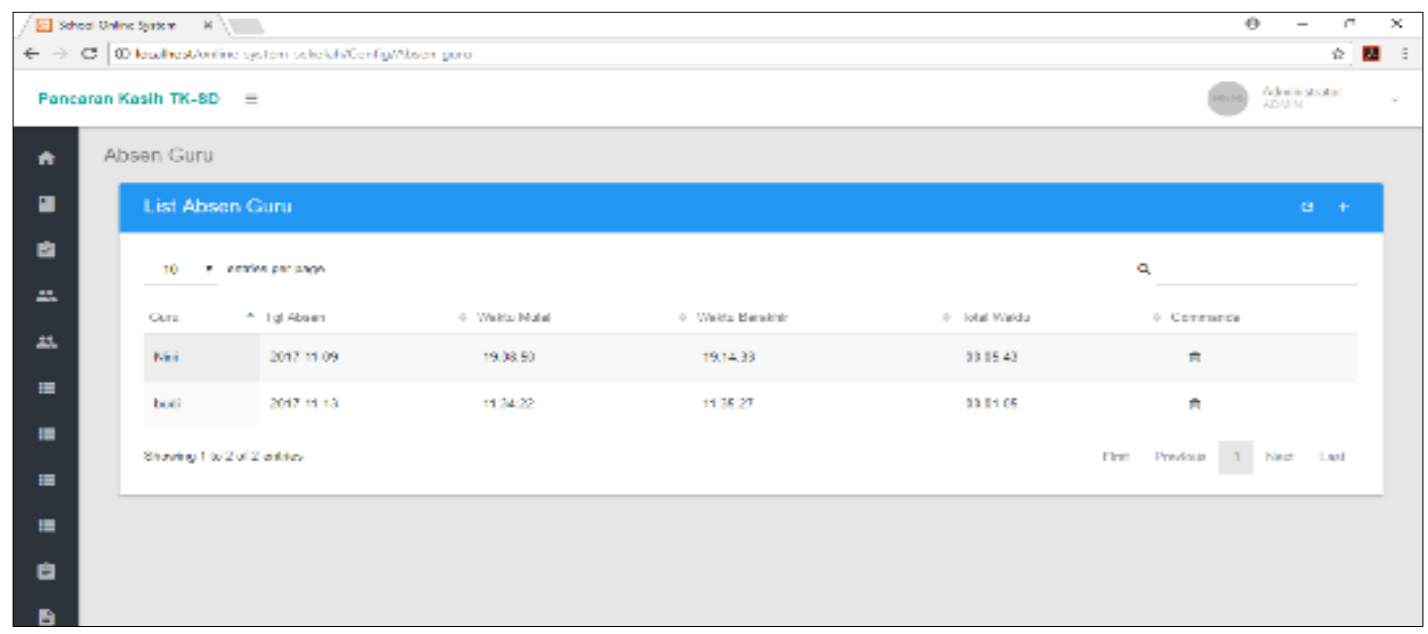

Gambar 6 Halaman Lihat Absen Guru

\section{Halaman Lihat Nilai Siswa}

Halaman nilai nilai siswa digunakan untuk menampilkan data nilai siswa di kelas. Data input nilai siswa yang ditampilkan pada halaman ini adalah data tanggal, waktu, kelas, mata pelajaran, nama siswa, Nilai kuis 1-5, Nilai UTS, Nilai UAS dan Nilai Akhir.

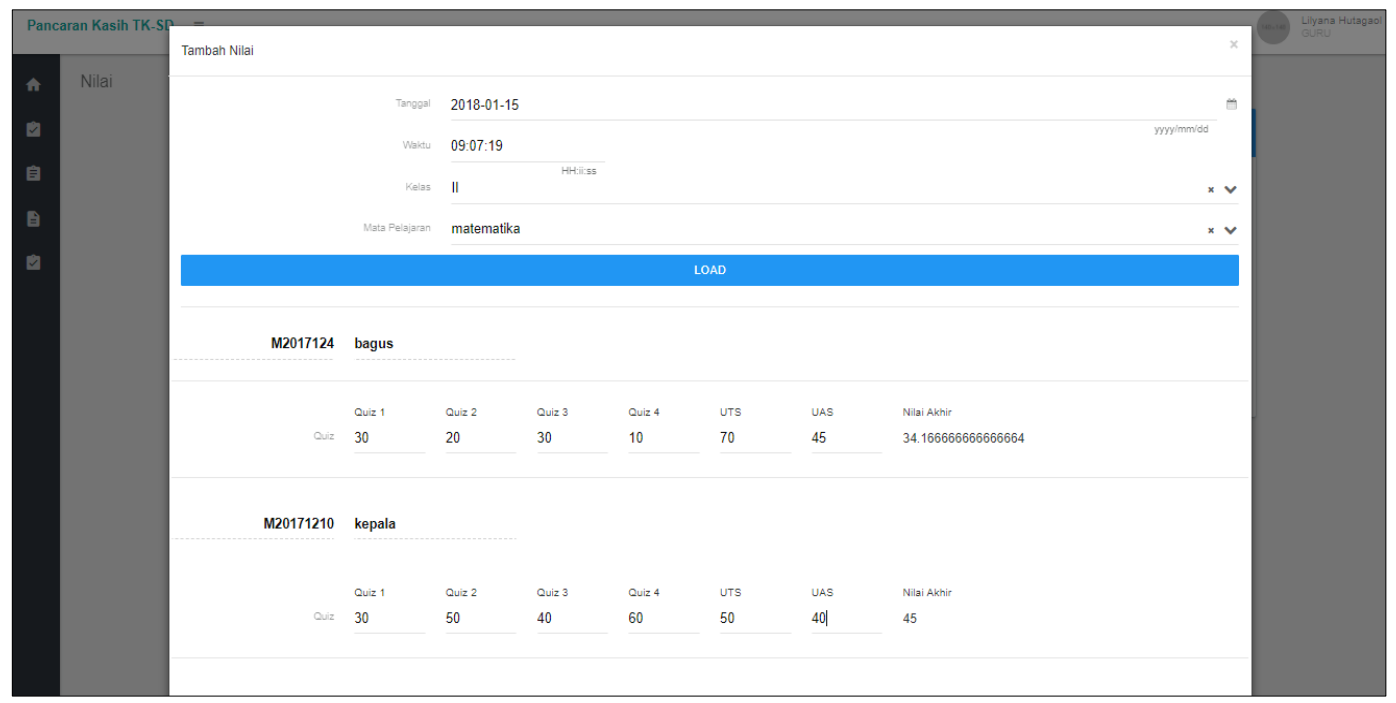

Gambar 7 Halaman Lihat Nilai Siswa

Admin dan kepala sekolah dapat melihat hasil nilai siswa dari masing-masing guru mulai dari Nilai kuis 1-4, Nilai UTS, Nilai UAS dan Nilai Akhir. Tampilan dapat dilihat pada gambar 7.

\section{Halaman lihat absen siswa}

Halaman nilai absen siswa digunakan untuk menampilkan data kehadiran siswa di kelas. Data absen siswa yang ditampilkan pada halaman ini adalah data nama siswa, semester, tahun ajaran, kelas, keterangan. 


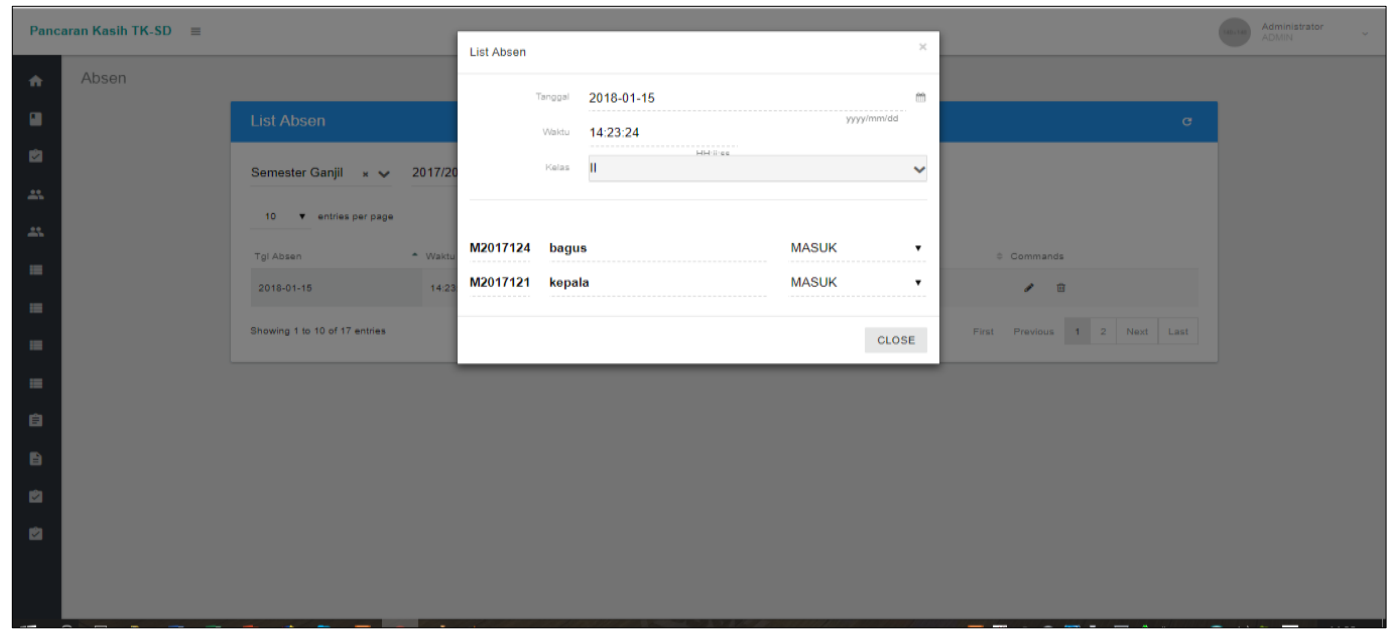

Gambar 8 Halaman Lihat Absen Siswa

Admin dan kepala sekolah dapat melihat data absen siswa dari masing-masing guru tiap kelasnya. Tampilan dapat dilihat pada gambar 8.

\section{Halaman lihat laporan kegiatan mengajar guru}

Halaman lihat laporan kegiatan mengajar digunakan untuk menampilkan data laporan kegiatan mengajar di kelas. Data kegiatan mengajar yang ditampilkan pada tampilan adalah data tanggal, waktu, laporan kegiatan, nama guru dan kelas

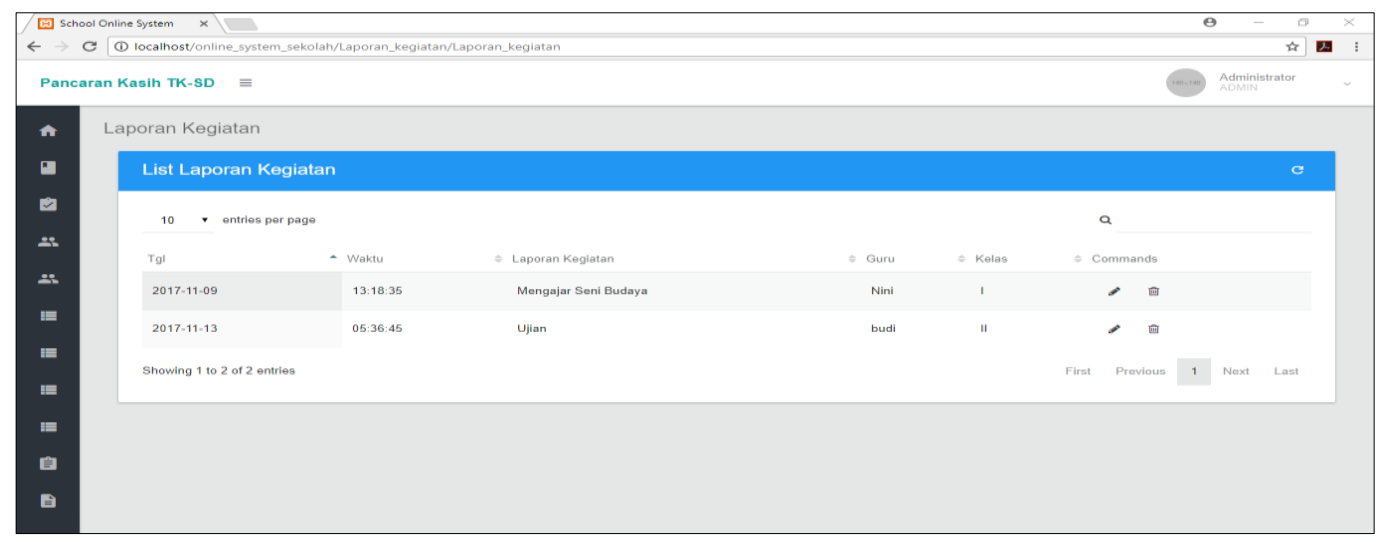

Gambar 9 Halaman Lihat Laporan Kegiatan Mengajar Guru

Admin dan kepala sekolah dapat melihat hasil laporan kegiatan menagajar guru selama mengajar di kelas. Tampilan dapat dilihat pada gambar 9.

\section{Pengujian}

Pengujian adalah hal yang perlu dilakukan untuk mengetahui kekurangan atau kesalahan pada perangkat lunak yang duji. Pengujian bermaksud untuk mengetahui perangkat lunak yang dibuat sudah memenuhi kriteria yang sesuai dengan tujuan perancangan perangkat lunak tersebut.

\section{Pengujian Black Box}

Black box testing adalah metode yang digunakan untuk menemukan kesalahan dan medemonstrasikan fungsional apilkasi saat dioperasikan, apakah input diterima dengan benar dan output yang dihasilkan telah sesuai dengan yang diharapkan.

Tujuan metode ini adalah mencari kesalahan pada:

1. Fungsi yang salah atau hilang

2. Kesalahan pada interface 
3. Kesalahan pada struktur data atau akses database

4. Kesalahan performasi

5. Kesalahan inisialisasi dan tujuan akhir

Berikut ini adalah kasus untuk menguji perangkat lunak yang sudah dibangun menggunakan metode Black Box. Rencana pengujian yang telah dibuat sebelumnya.

Berikut ini adalah tabel pengujian login untuk admin

Tabel 4.1 Pengujian Fungsi Login (Admin)

Kasus dan Hasil Uji (Data Normal)

\begin{tabular}{|c|c|c|c|}
\hline Data Masukkan & Yang Diharapkan & Pengamatan & Kesimpulan \\
\hline $\begin{array}{l}\text { Username } \\
\text { administrator } \\
\text { Password : } \\
\text { Admin }\end{array}$ & $\begin{array}{lr}\text { Teks administrator } \\
\text { diinput pada kotak } \\
\text { username, teks } \\
\text { password diinput } \\
\text { padar } \\
\text { password }\end{array}$ & $\begin{array}{lr}\text { Username } & \\
\text { administrator } \\
\text { terinput pada kotak } \\
\text { username, } \\
\text { (asteriks) terinput } \\
\text { pada } \\
\text { password }\end{array}$ & $\begin{array}{l}\text { Username dan } \\
\text { password diterima }\end{array}$ \\
\hline Klik tombol login & $\begin{array}{l}\text { Data username dan } \\
\text { password berhasil } \\
\text { ditemukan untuk } \\
\text { masuk ke main } \\
\text { page }\end{array}$ & $\begin{array}{l}\text { Tombol login atau } \\
\text { dengan menekan } \\
\text { enter berfungsi }\end{array}$ & $\begin{array}{l}\text { Tombol } \\
\text { diterima }\end{array}$ \\
\hline
\end{tabular}

\begin{tabular}{|c|c|c|c|}
\hline \multicolumn{4}{|c|}{ Kasus dan Hasil Uji (Data Salah) } \\
\hline Data Masukkan & Yang Diharapkan & Pengamatan & Kesimpulan \\
\hline $\begin{array}{l}\text { Nama Pengguna : } \\
\text { administrator } \\
\text { Password : } \\
\text { Admin }\end{array}$ & $\begin{array}{lr}\text { Teks administrator } \\
\text { diinput pada kotak } \\
\text { username, } r \text { teks } \\
\text { password } \\
\text { padiinput } \\
\text { password } & \text { kotak } \\
\end{array}$ & $\begin{array}{lr}\text { Username } & \\
\text { administrator } \\
\text { terinput pada kotak } \\
\text { username, } \\
\text { (asteriks) } \\
\text { pada } \\
\text { password } & \\
\end{array}$ & $\begin{array}{l}\text { Username dan } \\
\text { password diterima }\end{array}$ \\
\hline Klik tombol login & $\begin{array}{l}\text { Data username dan } \\
\text { password tidak } \\
\text { ditemukan sehingga } \\
\text { tidak bisa masuk ke } \\
\text { main page }\end{array}$ & $\begin{array}{l}\text { User gagal untuk } \\
\text { melakukan login ke } \\
\text { main page }\end{array}$ & $\begin{array}{l}\text { Tombol } \\
\text { diterima }\end{array}$ \\
\hline
\end{tabular}

Berikut ini adalah tabel pengujian tambah kelas untuk admin

Tabel 4.2 Pengujian Fungsi Tambah Data Kelas (Admin)

\begin{tabular}{|l|l|l|l|}
\hline \multicolumn{4}{|l|}{ Kasus dan Hasil Uji (Data Normal) } \\
\hline Data Masukkan & Yang Diharapkan & Pengamatan & Kesimpulan \\
\hline $\begin{array}{l}\text { Klik tombol tambah } \\
\text { kelas }\end{array}$ & $\begin{array}{l}\text { Kotak Tambah kelas } \\
\text { muncul }\end{array}$ & $\begin{array}{l}\text { Tampil kotak } \\
\text { tambah kelas }\end{array}$ & Diterima \\
\hline $\begin{array}{l}\text { Kelas : 6 } \\
\text { Deskripsi : SD }\end{array}$ & $\begin{array}{l}\text { Input "6" di kotak } \\
\text { Kelas, Input "SD" di } \\
\text { kotak Deskripsi }\end{array}$ & $\begin{array}{l}\text { Tampil "6" di kotak } \\
\text { kelas, tampil "SD" di } \\
\text { kotak deskripsi }\end{array}$ & Diterima \\
\hline Klik Tombol Save & $\begin{array}{l}\text { Data kelas 6 SD } \\
\text { berhasil disimpan }\end{array}$ & $\begin{array}{l}\text { Tampil kotak } \\
\text { localhost "success" }\end{array}$ & Diterima \\
\hline Klik tombol Delete & $\begin{array}{l}\text { Data kelas 6 SD } \\
\text { berhasil dihapus }\end{array}$ & $\begin{array}{l}\text { Tampil kotak } \\
\text { localhost "success" }\end{array}$ & Diterima \\
\hline Klik tombol edit & $\begin{array}{l}\text { Muncul kotak } \\
\text { tambah kelas untuk } \\
\text { merubah data }\end{array}$ & $\begin{array}{l}\text { Tampil kotak } \\
\text { tambah kelas }\end{array}$ & Diterima \\
\hline
\end{tabular}




\begin{tabular}{|l|l|l|l|}
\hline \multicolumn{4}{|l|}{ Kasus dan Hasil Uji (Data Salah) } \\
\hline Data Masukkan & Yang Diharapkan & Pengamatan & Kesimpulan \\
\hline $\begin{array}{l}\text { Klik tombol tambah } \\
\text { kelas }\end{array}$ & $\begin{array}{l}\text { Input "6" di kotak } \\
\text { Kelas, kotak } \\
\text { Deskripsi kosong }\end{array}$ & $\begin{array}{l}\text { Kotak Deskripsi } \\
\text { menjadi warna } \\
\text { merah }\end{array}$ & $\begin{array}{l}\text { Data yang diinput } \\
\text { tidak diterima } \\
\text { sistem }\end{array}$ \\
\hline Klik tombol save & $\begin{array}{l}\text { Data bisa disimpan } \\
\text { walaupun deskripsi } \\
\text { kosong }\end{array}$ & $\begin{array}{l}\text { Dataragal gatimpan } \\
\text { disimpan }\end{array}$ & Data tidak disimpan \\
\end{tabular}

\section{Pengujian Fungsi Tambah Murid}

Berikut ini adalah tabel pengujian tambah data murid untuk admin

Tabel 4.3 Pengujian Fungsi Tambah Data Murid (Admin)

\begin{tabular}{|c|c|c|c|}
\hline \multicolumn{4}{|c|}{ Kasus dan Hasil Uji (Data Normal) } \\
\hline Data Masukkan & Yang Diharapkan & Pengamatan & Kesimpulan \\
\hline $\begin{array}{l}\text { Klik tombol tambah } \\
\text { murid }\end{array}$ & $\begin{array}{l}\text { Muncul kotak } \\
\text { tambah murid }\end{array}$ & $\begin{array}{l}\text { Tampil kotak } \\
\text { tambah murid }\end{array}$ & Diterima \\
\hline $\begin{array}{l}\text { Nama : Yeremia } \\
\text { Tanggal lahir : } 19 \\
\text { November } 2007 \\
\text { Agama : Advent } \\
\text { Alamat : } \\
\text { Pejompongan no. } \\
20 \\
\text { Lulusan : TK } \\
\text { Kelas : VI }\end{array}$ & $\begin{array}{l}\text { Memasukkan data } \\
\text { murid di kotak } \\
\text { nama, tanggal lahir, } \\
\text { agama, alamat, } \\
\text { lulusan, kelas. }\end{array}$ & $\begin{array}{l}\text { Data yang diinput } \\
\text { muncul di kotak } \\
\text { yang tersedia }\end{array}$ & \\
\hline $\begin{array}{l}\text { Klik Tombol Kelas } \\
\text { dan Mata Pelajaran }\end{array}$ & $\begin{array}{l}\text { Muncul kotak kelas } \\
\text { dan mapel murid }\end{array}$ & $\begin{array}{l}\text { Tampil kotak kelas } \\
\text { dan mapel murid }\end{array}$ & \\
\hline $\begin{array}{l}\text { Nama : Yeremia } \\
\text { Tahun ajaran : } \\
2017 / 2018 \\
\text { Semester : genap } \\
\text { Kelas : VI } \\
\text { Mata pelajaran : } \\
\text { PKN, Seni Budaya }\end{array}$ & $\begin{array}{l}\text { Memasukkan data } \\
\text { nama murid, tahun } \\
\text { ajaran, semester, } \\
\text { kelas dan mapel. }\end{array}$ & $\begin{array}{l}\text { Data yang diinput } \\
\text { muncul di kotak } \\
\text { yang telah tersedia }\end{array}$ & Data diterima \\
\hline Klik tombol save & $\begin{array}{l}\text { Data berhasil } \\
\text { disimpan }\end{array}$ & $\begin{array}{lr}\text { Muncul } & \text { pesan } \\
\text { localhost } & \text { "success" } \\
\text { data } & \text { berhasil } \\
\text { disimpan } & \\
\end{array}$ & diterima \\
\hline Klik tombol View & $\begin{array}{l}\text { Muncul kotak View } \\
\text { Kelas dan Mapel } \\
\text { Murid }\end{array}$ & $\begin{array}{l}\text { Tampil kotak View } \\
\text { Kelas dan Mapel } \\
\text { Murid }\end{array}$ & Diterima \\
\hline Klik tombol hapus & $\begin{array}{l}\text { Data yang ingin } \\
\text { dihapus terhapus }\end{array}$ & $\begin{array}{l}\text { Data murid yang } \\
\text { ingin dihapus telah } \\
\text { terhapus }\end{array}$ & Diterima \\
\hline Klik tombol edit & $\begin{array}{l}\text { Muncul kotak } \\
\text { tambah murid yang } \\
\text { ingin diedit }\end{array}$ & $\begin{array}{l}\text { Tampil kotak view } \\
\text { kelas dan mapel } \\
\text { murid yang ingin } \\
\text { diedit }\end{array}$ & Diterima \\
\hline \multicolumn{4}{|c|}{ Kasus dan Hasil Uji (Data Salah) } \\
\hline Data Masukkan & Yang Diharapkan & Pengamatan & Kesimpulan \\
\hline $\begin{array}{l}\text { Semua data tidak } \\
\text { diisi }\end{array}$ & $\begin{array}{lr}\text { Akan } & \text { muncul } \\
\text { informasi } & \text { gagal } \\
\end{array}$ & $\begin{array}{lr}\text { Kotak } & \text { yang tidak } \\
\text { diisi } & \text { menjadi } \\
\end{array}$ & diterima \\
\hline
\end{tabular}




\begin{tabular}{|l|l|l|l|}
\hline & $\begin{array}{l}\text { menambah data } \\
\text { murid }\end{array}$ & $\begin{array}{l}\text { berwarna merah, } \\
\text { data gagal disimpan }\end{array}$ & \\
\hline
\end{tabular}

\section{Pengujian Fungsi Tambah Data Guru}

Berikut ini adalah tabel pengujian tambah data guru untuk admin

Tabel 4.4 Pengujian Fungsi Tambah Data Guru (Admin)

\begin{tabular}{|c|c|c|c|}
\hline \multicolumn{4}{|c|}{ Kasus dan Hasil Uji (Data Normal) } \\
\hline Data Masukkan & Yang Diharapkan & Pengamatan & Kesimpulan \\
\hline $\begin{array}{l}\text { Klik tombol tambah } \\
\text { Guru }\end{array}$ & $\begin{array}{ll}\text { Muncul kotak } \\
\text { tambah guru }\end{array}$ & $\begin{array}{ll}\text { Tampil kotak } \\
\text { tambah guru }\end{array}$ & diterima \\
\hline $\begin{array}{l}\text { Nama : Dwi octa } \\
\text { Tanggal lahir : } \\
1994-10-02 \\
\text { Agama : Advent } \\
\text { Alamat :Jl blauran } \\
\text { Lulusan :S1 Biologi } \\
\text { Password } \\
: 1234\end{array}$ & Sesuai & Sesuai & diterima \\
\hline Klik Tombol Save & Tersimpan & Tersimpan & Diterima \\
\hline $\begin{array}{l}\text { Klik tombol Kelas } \\
\text { dan Mata Pelajaran }\end{array}$ & Muncul kotak & Muncul kotak & Diterima \\
\hline $\begin{array}{l}\text { Nama: dwi octa } \\
\text { Tahun ajaran: } \\
2017 / 2018 \\
\text { Semester } \\
\text { semester ganjil } \\
\text { Kelas : } 1 \\
\text { Mata Pelajaran : } \\
\text { Matematika } \\
\end{array}$ & Sesuai & Sesuai & Diterima \\
\hline Klik Tombol View & Muncul kotak & Muncul kotak & Diterima \\
\hline Klik Tombol Edit & Muncul kotak edit & Muncul kotak & Diterima \\
\hline
\end{tabular}

\begin{tabular}{|l|l|l|l|}
\hline \multicolumn{4}{|l|}{ Kasus dan Hasil Uji (Data Salah) } \\
\hline Data Masukkan & Yang Diharapkan & Pengamatan & Kesimpulan \\
\hline $\begin{array}{l}\text { Semua data tidak } \\
\text { diisi }\end{array}$ & Tidak berfungsi & Tidak berfungsi & Diterima \\
\hline & & & \\
\hline
\end{tabular}

\section{Pengujian Fungsi Absen Siswa}

Berikut ini adalah tabel pengujian List absen siswa untuk admin

Tabel 4.5 Pengujian Fungsi List Absen Siswa (Admin)

\begin{tabular}{|l|l|l|l|}
\hline \multicolumn{4}{|l|}{ Kasus dan Hasil Uji (Data Normal) } \\
\hline $\begin{array}{l}\text { Data Masukkan } \\
\text { Klik tombol list }\end{array}$ & Mung Diharapkan & Pengamatan & Kesimpulan \\
\hline Klik tombol hapus & Terhapus & Muncul & Diterima \\
\hline
\end{tabular}

Kasus dan Hasil Uji (Data Salah) 


\begin{tabular}{|l|l|l|l|}
\hline Data Masukkan & Yang Diharapkan & Pengamatan & Kesimpulan \\
\hline $\begin{array}{l}\text { Klik tombol list } \\
\text { absen }\end{array}$ & Muncul tampilan & Muncul tampilan & Diterima \\
\hline Klik tombol hapus & Terhapus & Terhapus & Diterima \\
\hline & & & \\
\hline
\end{tabular}

\section{Pengujian Fungsi Tambah Mata Pelajaran}

Berikut ini adalah tabel pengujian tambah data mata pelajaran untuk admin

Tabel 4.6 Pengujian Fungsi Tambah Data Mata Pelajaran (Admin)

\begin{tabular}{|l|l|l|l|}
\hline \multicolumn{4}{|l|}{ Kasus dan Hasil Uji (Data Normal) } \\
\hline Data Masukkan & Yang Diharapkan & Pengamatan & Kesimpulan \\
\hline $\begin{array}{l}\text { Klik tombol tambah } \\
\text { mata pelajaran }\end{array}$ & Muncul tampilan & Muncul tampilan & Diterima \\
\hline $\begin{array}{l}\text { Mata Pelajaran : } \\
\text { bahasa indonesia } \\
\text { Deskripsi } \\
\text { pelajaran }\end{array}$ & Sesuai & Sesuai & Diterima \\
\hline Klik Tombol Save & Tersimpan & Tersimpan & \\
\hline Klik tombol Delete & Terhapus & Terhapus & Diterima \\
\hline Klik tombol Edit & Bisa merubah & Bisa merubah & Diterima \\
\hline
\end{tabular}

\begin{tabular}{|l|l|l|l|}
\hline \multicolumn{4}{|l|}{ Kasus dan Hasil Uji (Data Salah) } \\
\hline Data Masukkan & Yang Diharapkan & Pengamatan & Kesimpulan \\
\hline $\begin{array}{l}\text { Semua data tidak } \\
\text { diisi }\end{array}$ & $\begin{array}{l}\text { Tidak sesuai } \\
\text { harapan }\end{array}$ & $\begin{array}{l}\text { Tidak sesuai } \\
\text { pengamatan }\end{array}$ & Diterima \\
\hline & & & \\
\hline
\end{tabular}

\section{Kesimpulan dan Saran \\ Kesimpulan}

Dari hasil perancangan pengembangan Sistem Informasi Absensi dan Nilai siswa beserta Absensi dan Laporan Kegiatan mengajar Guru di Sekolah Advent Pancaran Kasih Surabaya, maka penulis dapat mengambil kesimpulan sebagai berikut:

1. Pengguna dapat melakukan proses pendataan sampai pelaporan dengan bantuan aplikasi ini.

2. Aplikasi ini dapat meningkatkan kedisiplinan siswa dalam proses belajar mengajar.

3. Aplikasi ini dapat membantu sekolah dalam meningkatkan kualitas pelayanan kepada siswasiswanya.

4. Sistem dapat memberikan informasi kehadiran dan nilai siswa kepada orang tua dengan mudah dan cepat.

5. Sistem dapat memberikan informasi kehadiran siswa kepada guru BP dengan mudah dan cepat.

6. Sistem dapat memberikan informasi kehadiran guru kepada kepala sekolah dengan mudah dan cepat.

7. Aplikasi ini memberikan informasi tentang nilai dan absen siswa beserta absensi guru dan laporan kegiatan mengajar guru.

\section{Saran}

Adapun saran yang diberikan penulis dalam menyempurnakan aplikasi ini adalah:

1. Sistem dapat mengelola data siswa dalam jangka waktu yang panjang, mulai dari siswa menjadi alumni.

2. Sistem dapat mengelola data alumni dan menunjukan data riwayat pendidikan selama masih menjadi siswa aktif. 


\section{Referensi}

1. A. Noertjahyana, 2012, Studi Analisis Rapid Application Development Sebagai Salah Satu Alternatif Metode Pengembangan Perangkat Lunak, Jurnal Informatika

2. Haviluddin, 2009. Memahami Penggunaan Diagram Arus Data. Jurnal Informatika mulawarma.

3. Hamidi, Sistem Informasi Geografi Berbasis Web Penyebaran Dana Bantuan Operasional Sekolah, Jurnal Masyarakat Informatika.

4. Isra Al Rais, 2010. Sistem Informasi Penjualan Pakaian Di Volltus Distro Bandung

5. Prof. Dr. Sugiyono. (2010). Metode Penelitian Pendidika: Pendekatan Kuantitatif, kualitatif,dan R\&D ,Bandung: Alfabeta Bandung

6. Riyan Eka Putra, 2015. SISTEM INFORMASI ABSENSI SISWA BERBASIS WEBSITE MENGGUNAKAN GAMMU SMS GATEWAY, PHP, DAN MYSQL

7. R. Novita dan Karluci, 2015. Sistem Inforamasi Pemetaan Daerah Terjangkit Demam Berdarah Dengue (DBD) Wilayah Kota Pekanbaru,urnal Rekayasa dan Manajemen Sistem Informasi. 1

8. Santoso IA. 2012. Analisis Dan Perancangan Sistem Informasi Rekam Medis Di RSKIA Bhakti Ibu. Jurnal. Yogyakarta: STMIK AMIKOM Yogyakarta.

9. Zuriati, 2002, Perancangan Sistem Informasi Penerimaan Mahasiswa Baru, Staf pengajar pada Program Studi Managemen Informatika Jurusan Ekonomi dan Bisnis Politeknik Negeri Lampung, vol. 6, no. 3, Juli 2012. Jurnal Ilmiah ESAI. 